\title{
Realitas formalis/realitas obiectiva. Paradoks Kartezjańskiego reprezentacjonizmu
}

Ogólnie rzecz ujmując, reprezentacjonizm można scharakteryzować jako stanowisko filozoficzne, zgodnie z którym umysł poznaje rzeczywistość jedynie za pośrednictwem przedstawień (a więc właśnie reprezentacji) czy też idei rzeczy ${ }^{1}$. Bezpośrednio dostępne dla podmiotu poznającego są więc na gruncie tego rodzaju koncepcji jedynie mentalne przedstawienia obiektów świata zewnętrznego. Niemniej od solipsyzmu stanowisko to różni się domniemaniem realnego istnienia reprezentowanej przez idee rzeczywistości pozaumysłowej, nawet jeśli $\mathrm{w}$ różnych odmianach reprezentacjonizmu rozmaicie rozwiązuje się kwestię przedmiotowej adekwatności przedstawień - od postulowania pełnej adekwatności przynajmniej niektórych idei (m.in. Descartes, Locke), aż po zakwestionowanie możliwości rozstrzygnięcia tego problemu (Kant).

Doktryny reprezentacjonistyczne można klasyfikować z różnych perspektyw, stosując rozmaite kryteria podziału. Do najbardziej kluczowych wśród nich należy kryterium odwołujące się do charakteru relacji zachodzącej między rzeczą i jej reprezentacją (a pośrednio także do statusu ontologicznego samej reprezentacji). Abstrahując i w tej kwestii od nieistotnych szczegółów, można, posługując się omawianym kryterium, rozróżnić dwa zasadnicze typy stanowisk reprezentacjonistycznych. Charakterystyczną cechą rozwią-

${ }^{1}$ Terminów „idea”, „reprezentacja” i „przedstawienie”, a także „rzecz”, „przedmiot” i „obiekt” używam w całym tekście synonimicznie. 
zań pierwszego rodzaju jest brak silnego ontologicznego związku między ideą a jej pozaumysłowym korelatem, opartego na dziedziczeniu przez ideę cech reprezentowanego obiektu. W ujęciach tego typu przedstawienie jest co najwyżej mentalnym obrazem, ikoną, a nawet jedynie symbolem rzeczy. Adekwatnego przykładu tego rodzaju relacji reprezentacji dostarcza reprezentacja językowa. Wyrażenia językowe nie mają bowiem - z punktu widzenia ich struktury i natury ontologicznej - nic wspólnego ze skorelowanymi z nimi obiektami. Co najwyżej odwzorowują one ikonicznie (w systemach piktograficznych) własności oznaczanych rzeczy, realnie ich nie posiadając ${ }^{2}$. Najczęściej jednak wyrażenia te mają charakter czysto abstrakcyjny - w większości systemów językowych znak, czy rozumie się przez niego pismo, dźwięk czy pomyślane słowo, pozbawiony jest jakiegokolwiek strukturalnego związku ze swoim desygnatem. Truizmem jest stwierdzenie, że terminy „słońce” czy „nieskończoność” nie posiadają żadnych własności skorelowanych z nimi semantycznie obiektów ${ }^{3}$.

Taki sposób ukształtowania relacji reprezentacji obarczony jest jednak licznymi wadami. Brak jakiegokolwiek ontologicznego „pokrewieństwa” między przedstawieniem i obiektem sprawia, że teza o przedmiotowej ważności i adekwatności reprezentacji, a nawet o samym zachodzeniu relacji reprezentowania jawi się jako czysto hipotetyczna bądź deklaratywna. Skorelowanie idei i rzeczy może mieć w tym wypadku charakter co najwyżej postulatywny, konwencjonalny, a więc de facto arbitralny. Wobec niemożliwości bezpośredniego poznania pozaumysłowych korelatów idei, a co za tym idzie weryfikacji relacji reprezentowania, brak ontologicznego powiązania zjawisk mentalnych i rzeczy sprawia, że nie tylko twierdzenie o adekwatności reprezentacji, lecz o samym reprezentacyjnym powiązaniu obiektów obu kategorii, a nawet w ogóle o istnieniu jakiejkolwiek rzeczywistości pozaumysłowej staje się kwestią domniemania, supozycji, nawyku, konwencji lub wiary - można jedynie postulować lub zakładać, że określona idea jest reprezentacyjnie skorelowana $\mathrm{z}$ jakimś obiektem ${ }^{4}$. W konsekwencji rozliczni krytycy mogą, jak

${ }^{2}$ Zob. wszakże krytykę ikonizmu w U. Eco, Teoria semiotyki, przeł. M. Czerwiński, Kraków 2009, s. 204-231.

${ }^{3}$ Przykład reprezentacji lingwistycznej stanowi tu oczywiście jedynie rodzaj przejrzystej ilustracji, występująca na jej gruncie korelacja zachodzi bowiem często między dwiema reprezentacjami.

${ }^{4}$ Mogłoby się wydawać, że związek przyczynowy zachodzący między rzeczą a jej percepcją dostarcza wystarczających gwarancji niearbitralności i obiektywności ich reprezentacyjnej korelacji. W rzeczywistości jednak niemożliwość bezpośredniego poznania obiektów poza 
młody Nietzsche, zanegować reprezentacyjny charakter języka czy poznania, podnosząc argument $\mathrm{z}$ ontologicznej heterogeniczności obu sfer: mentalnych przedstawień i rzeczy ${ }^{5}$.

Słabości tego typu koncepcji zniwelować ma odmienny rodzaj reprezentacjonizmu, podkreślający silny, ontologiczny związek między przedstawieniem i rzeczą - oparty na identyczności własności obu obiektów. W tym wariancie omawianego stanowiska epistemologicznego przysługujący idei status reprezentacji określonego przedmiotu wynika wprost ze strukturalnego, ontologicznego „pokrewieństwa” z nim. Idea stanowi naturalną reprezentację pewnego pozaumysłowego obiektu na mocy łączącej ją z nim wspólnoty własności i ontologicznej budowy. W efekcie, także sama relacja reprezentowania, ugruntowana jako związek o charakterze ontologicznym zyskuje znamiona nie-arbitralności i naturalności ${ }^{6}$. W konsekwencji, rozwiązanie to wychodzi naprzeciw naturalnemu przeświadczeniu o konieczności istnienia pewnej obiektywnej racji, zasady zachodzenia związku reprezentacyjnego, wyrażonego dobitnie w Wittgensteinowskim Traktacie: „2.16 Aby być obrazem, fakt musi mieć coś wspólnego z tym, co odwzorowuje”, „2.161 W obrazie i w tym, co odwzorowane, coś musi być identyczne, aby w ogóle jedno mogło być obrazem drugiego"?

System Descartesa stanowi, jak powszechnie wiadomo, modelowy przykład stanowiska reprezentacjonistycznego. Co więcej, jest jego przypadkiem paradygmatycznym - to od Kartezjańskiej rewolucji rozpoczynają się dzieje całego nowożytnego reprezentacjonizmu. Zarazem jednak teoria Descartesa zawiera niezwykle ciekawą i oryginalną koncepcję reprezentacji, a fakt ten nie zawsze dostrzegano lub nie chciano dostrzegać - rozważając dwa, omówione wyżej, rodzaje reprezentacjonizmu, większość badaczy byłaby

umysłem podaje w wątpliwość samo twierdzenie o zachodzeniu kauzalnego związku między nimi a ideami. W konsekwencji liczne twierdzenia dotyczące reprezentacyjnego skorelowania idei i rzeczy, np. że dana idea wywoływana jest przez ten, a nie inny obiekt, że określone idee mają swe przyczynowe korelaty, a inne nie (np. wrażenia doświadczane we śnie), że niektóre idee (np. kształtu) mają funkcję reprezentacyjną, a więc odzwierciedlają własności jakichś zewnętrznych obiektów, od których są przyczynowo zależne, a inne nie (np. ból wywołany kopnięciem), okazują się czysto nawykowe lub konwencjonalne.

${ }^{5}$ Zob. np. F. Nietzsche, O prawdzie i kłamstwie w pozamoralnym sensie, [w:] idem, Pisma pozostałe 1862-1875, tłum. B. Baran, Kraków 1993, s. 181-199.

${ }^{6}$ Inna sprawa, że wraz z przyjęciem omawianego rozwiązania problematyczna staje się z kolei prawomocność i niearbitralność owego wygodnego założenia o ontologicznym izomorfizmie rzeczy i idei.

${ }^{7}$ L. Wittgenstein, Tractatus logico-philosophicus, tłum. B. Wolniewicz, Warszawa 2002, s. 10. 
zapewne skłonna zaliczyć system Descartesa do koncepcji pierwszego typu. Kartezjańskie idee miałyby więc pełnić w takim ujęciu jedynie funkcję swego rodzaju mentalnych obrazów, pozbawionych związku ontologicznego ze skorelowanymi z nimi obiektami materialnymi. Tymczasem interpretacja ta nie znajduje żadnego uzasadnienia w tekście samych Medytacji. Mogą ją, co najwyżej, pośrednio sugerować fragmenty w rodzaju: „idee są we mnie jak gdyby obrazami" ", choć i one skłaniają do pytania o rację owego obrazowania, termin „obraz” sugeruje zaś nadto istnienie jakiegoś strukturalnego podobieństwa idei i rzeczy. Sugestię te wzmacniają dodatkowo wypowiedzi w rodzaju: „rzecz [...] przekazuje mi [...] swoją podobiznę" lektura Kartezjańskiego tekstu rozwiewa już jednak wszystkie złudzenia, pokazując niezbicie, że relacja reprezentowania jest w tym systemie ukształtowana niezwykle specyficznie, oryginalnie i - z punktu widzenia późniejszych dziejów reprezentacjonizmu - dość radykalnie.

Przede wszystkim warto zauważyć, że idea nie jest dla Descartesa (lub przynajmniej jest nie tylko) ikoną, symbolem czy znakiem, a nawet zwykłym mentalnym obrazem, percepcją obiektu materialnego, ale przedmiotem ontologicznie ustrukturowanym obiektem, posiadającym istotę, określony zespół cech i własny sposób istnienia ${ }^{10}$. Co więcej, własności idei ściśle korespondują z własnościami reprezentowanej przez nią rzeczy. Idea nie jest więc jedynie swego rodzaju obrazem cech przedmiotu materialnego. Sama ona posiada (we właściwy dla siebie sposób, o czym dalej) własności swego pozaumysłowego korelatu i właśnie ów strukturalny izomorfizm służy za fundament zachodzącej między tymi obiektami relacji reprezentowania ${ }^{11}$.

${ }^{8}$ R. Descartes, Medytacje o pierwszej filozofii. Zarzuty uczonych mężów wraz z odpowiedziami autora, tłum. M. i K. Ajdukiewiczowie, S. Swieżawski, t. 1, Warszawa 2010, s. 47.

9 Tamże, s. 43.

${ }^{10}$ Zob. np. cytowane w tym tekście fragmenty Medytacji. Descartes zazwyczaj nadaje przedmiotowość samej idei, niekiedy jednak pisze o przedmiocie uobecniającym się „W idei”, co sugerowałoby dwustronność jej budowy, w sensie zbliżonym do Ingardenowskiego. Jest on zresztą świadomy tej ambiwalencji: „...w słowie idea jest dwuznaczność, można ją bowiem rozumieć albo w sposób materialny (materialiter) jako czynność intelektu i w tym sensie nie można powiedzieć, że jest doskonalsza ode mnie, albo też w sposób obiektywny jako rzecz, którą ta czynność intelektu przedstawia..." (Medytacje..., s. 17). Dla uproszczenia, w niniejszym tekście przyjmuję konsekwentnie owo drugie - preferowane przez samego Descartesa rozumienie terminu „idea”. Odmienny wybór nie miałby zresztą wpływu na prawomocność prowadzonych tu rozważań, tyle tylko, że odnosiłyby się one wówczas nie do samej idei (pojętej jako czynność intelektu), lecz do urzeczywistniającego się w niej przedmiotu.

${ }^{11}$ Zob. szereg wypowiedzi Descartesa cytowanych w niniejszym tekście. 
Zaistnienie tego ontologicznego paralelizmu jest zaś możliwe dzięki temu, że stosunek między reprezentacją a tym, co reprezentowane (ideą i rzeczą materialną) zostaje ukonstytuowany na bazie kauzalnej, wytwórczej relacji przenoszenia własności - identycznej z tą, która prowadzi do powstania obiektów w świecie materialnym. Pogląd Descartesa jest w tej materii jednoznaczny: „... ani żadna rzecz nie może powstać z niczego, ani też rzecz doskonalsza, tzn. taka, która zawiera w sobie więcej rzeczywistości, nie może powstać z mniej doskonałej; i to jest oczywistą prawdą nie tylko w odniesieniu do tych skutków, których rzeczywistość jest aktualna lub formalna, ale także w odniesieniu do idei, w których wchodzi w grę tylko rzeczywistość obiektywna. To znaczy, że nie tylko nie może - na przykład - zacząć istnieć teraz jakiś kamień, którego przedtem nie było, o ile nie zostałby wytworzony przez jakąś rzecz, która by zawierała w sposób formalny (formaliter) albo eminentny (eminenter) wszystko to, co przysługuje kamieniowi; nie może też ciepło przeniknąć żadnego przedmiotu, który tego ciepła przedtem nie posiadał [...] Ale oprócz tego nie może istnieć we mnie idea ciepła czy kamienia, o ile by mi jej nie przekazała jakaś przyczyna, która by zawierała przynajmniej tyle rzeczywistości, ile myślę, że jest w cieple czy kamieniu”" ${ }^{12}$.

Kartezjańska relacja reprezentacji opiera się więc nie na jakimś symbolicznym, postulatywnym czy konwencjonalnym przyporządkowywaniu idei rzeczy, na jakimś arbitralnym „chrzcie pierwotnym” korelującym zjawisko mentalne z materialnym przedmiotem, ani nawet na zwykłym oddziaływaniu kauzalnym, w wyniku którego w umyśle pojawia się percepcja rzeczy. Jej fundamentem jest przekaz własności, metafizyczne duplikowanie obiektu w umyśle - wytwarzanie w nim kopii rzeczy o określonych cechach. Takie ustrukturowanie relacji reprezentacji - określmy tę koncepcję mianem izomorfistycznej - sprawia nie tylko, że uzyskuje ona ontologiczne ugruntowanie, a wraz z nim znamiona naturalności i obiektywności. Dostarcza ono także gwarancji adekwatności przedstawień (przynajmniej niektórych ${ }^{13}$ ) skoro idea jest wyposażoną w przedmiotowość kopią rzeczy materialnej, powielającą jej własności, musi ona, za sprawą samej swej ontologicznej struktury, adekwatnie odzwierciedlać ją w umyśle.

\footnotetext{
12 Tamże, s. 46, zob. także fragmenty cytowane dalej.

${ }^{13} \mathrm{~W}$ prowadzonych tu analizach abstrahuję od klasy idei reprezentujących przedmioty egzystujące w sposób eminentny, jako że w ich przypadku nie może być mowy o izomorfistycznej teorii reprezentacji.
} 
Dlaczego Descartes zdecydował się na taką właśnie konstrukcję teoretyczną? Kluczową rolę odegrały, jak się wydaje, dwie racje. Po pierwsze, przyjęcie izomorfistycznej koncepcji reprezentowania, opartej na dziedziczeniu przez ideę własności jej pozaumysłowej przyczyny, stanowi niezbędny warunek funkcjonowania dowodu na istnienie Boga, przedstawionego w Trzeciej medytacji. Po wtóre, przyjęcia tej koncepcji wymaga także Kartezjański dowód istnienia świata materialnego, bazujący na założeniu, iż rzecz egzystująca w obiektywnym sposobie istnienia musi mieć za przyczynę obiekt, bytujący $\mathrm{w}$ formalnym sposobie egzystowania ${ }^{14}$.

Ostatecznie na gruncie koncepcji Descartesa mamy więc do czynienia z dwoma strukturalnie identycznymi obiektami sprzężonymi kauzalno-wytwórczą relacją przekazu własności, a więc z rzeczą materialną istniejącą poza umysłem i jej dubletem w umyśle, tj. ideą. Takie rozwiązanie rodzi jednak poważny problem teoretyczny: czy w omawianej sytuacji występują rzeczywiście dwa różne obiekty, czy też może raczej jeden obiekt uobecniający się w intelekcie i poza nim? Skoro bowiem przedmiot odgrywający rolę mentalnego przedstawienia rzeczy materialnej (idea) dziedziczy własności owego, reprezentowanego przez siebie obiektu, zastosowanie Leibniziańskiego kryterium identyczności sugerowałoby utożsamienie obu przedmiotów. W konsekwencji należałoby przyjąć, że jedna i ta sama rzecz urzeczywistnia się w umyśle (jako idea) oraz poza nim (jako obiekt materialny). Na postawione wyżej pytanie Descartes udziela wszelako najczęściej odpowiedzi przeciwnej: idea i jej pozaumysłowy korelat są dwoma różnymi przedmiotami ${ }^{15}$. Na czym jednak w takim razie zasadza się różnica między nimi? Kartezjańska odpowiedź jest

${ }^{14}$ Descartes, Medytacje, s. 83: „zdolność wytwarzania [...] idei [...] znajduje się [...] w jakiejś substancji różnej ode mnie. A ponieważ w tej substancji musi zawierać się w sposób formalny lub eminentny cała rzeczywistość zawarta w sposób obiektywny w ideach wytworzonych przez ową zdolność [...] jest więc tą substancją albo ciało tzn. natura cielesna, w której jest zawarte formalnie wszystko to, co w ideach zawiera się obiektywnie; albo też jest nią Bóg lub jakieś stworzenie szlachetniejsze od ciała, które zawiera w sobie ową rzeczywistość w sposób eminentny. Otóż jest rzeczą całkiem oczywistą, że ponieważ Bóg nie jest zwodzicielem, nie przekazuje mi tych idei ani bezpośrednio od siebie, ani za pośrednictwem jakiegoś stworzenia, w którym by zawierała się ta obiektywna rzeczywistość nie w sposób formalny, lecz tylko eminentny. Skoro bowiem Bóg nie dał mi żadnej zdolności, by to poznać, lecz przeciwnie wielką skłonność do uwierzenia, że pochodzą one od rzeczy cielesnych, nie widzę, w jaki sposób można by pojąć, że nie jest on zwodzicielem, jeśliby one pochodziły skądinąd niż od rzeczy cielesnych. A zatem rzeczy cielesne istnieją". Zob. także tamże s. 45-47.

${ }^{15}$ Zob. np. przytaczane wcześniej fragmenty o zachodzącym między nimi związku przyczynowym. 
z pozoru prosta: na odmienności właściwych obu tym obiektom sposobów istnienia. Podczas gdy idea bytuje w umyśle w sposób obiektywny (realitas obiectiva), jej materialny korelat egzystuje poza umysłem w sposób formalny (realitas formalis) ${ }^{16}$. Czy jednak to pozornie eleganckie rozwiązanie można uznać za satysfakcjonujące i spójne teoretycznie? Bliższa analiza omawianej konstrukcji metafizycznej skłania do ostrożności. W istocie kluczowe znaczenie dla odpowiedzi na powyższe pytanie ma ustalenie czy różnica w sposobie istnienia idei i rzeczy materialnej ma charakter realny (przedmiotowy) - czy jest ona wystarczająca do zachowania przedmiotowej odrębności obu tych obiektów? Kwestia ta sprowadza się zaś de facto do zagadnienia konstytutywności przynależnych im sposobów istnienia.

Pisząc o owej konstytutywności, nie mam oczywiście na myśli klasycznego, scholastycznego zagadnienia przynależności istnienia do istoty, które w odniesieniu do wszystkich, poza Bogiem, obiektów Kartezjańskiego uniwersum należałoby oczywiście rozstrzygnąć negatywnie - jest jasne, że w systemie Descartesa nie znajdziemy żadnego ontologicznego dowodu na istnienie świata materialnego czy świata idei. Przez konstytutywność sposobu istnienia obiektu (w omawianym przypadku idei bądź rzeczy materialnej) rozumiem taką właściwość jego metafizycznej budowy, że egzystowanie w określonym sposobie bytowania decyduje lub współdecyduje o jego przedmiotowej tożsamości. Innymi słowy, sposób istnienia takiego przedmiotu determinuje jego naturę - określa lub współokreśla czym ów przedmiot jest. „Egzystowanie w określonym sposobie istnienia należy” więc do „przedmiotowo konstytutywnych elementów, momentów, komponentów, aspektów lub własności obiektu - decydujących o jego rodzajowej, gatunkowej czy indywidualnej charakterystyce"17. I na odwrót: natura, przedmiotowa tożsamość obiektu autonomicznego względem sposobu istnienia w najmniejszym stopniu nie zależy od jego realizacji w jakimś konkretnym sposobie bytowania. W konsekwencji, ponieważ tożsamość takiego przedmiotu nie jest współkonstytuowana przez sposób istnienia, może on urzeczywistniać się w wielu różnych sposobach egzystowania. W nietemporalnym sensie tego słowa pozostaje on bowiem pierwotny względem każdego z tych sposobów, które z punktu widzenia konstytuowania przedmiotowej charakterystyki pełnią $\mathrm{w}$ jego metafizycznej strukturze funkcję czysto akcydentalną ${ }^{18}$.

\footnotetext{
${ }^{16}$ Zob. np. cytowane dalej fragmenty Medytacji.

${ }^{17}$ B. Żukowski, Esse est percipi? Metafizyka idei George’a Berkeleya, Kęty 2012, s. 48-49.

${ }^{18}$ Bardziej szczegółowo omawiam tę problematykę w książce Esse est percipi?, s. 47-57.
} 
Skoro Kartezjańska idea oraz jej pozaumysłowy korelat różnią się między sobą jedynie sposobem istnienia, przypisanie konstytutywności sposobu bytowania obu tym obiektom stanowi konieczny warunek zachowania ich przedmiotowej odrębności ${ }^{19}$. W przeciwnym razie zastosowanie kryterium Leibniza zmuszałoby do ich utożsamienia ${ }^{20}$. Skoro bowiem różnica między Kartezjańską ideą, bytującą w sposób obiektywny, a jej pozaumysłowym korelatem, obdarzonym formalnym sposobem egzystowania sprowadzałaby się jedynie do różnicy w sposobie istnienia, a odmienność ta w żaden sposób nie wpływałaby na tożsamość obu przedmiotów - brakowało by podstaw do ich odróżnienia. W konsekwencji rozróżnienie idei i rzeczy materialnej sprowadzałoby się wyłącznie do odróżnienia dwóch sposobów realizacji, dwóch różnych egzystencjalnych form uobecnienia (realności) tego samego przedmiotu, istniejącego w umyśle w sposób obiektywny, a poza nim w sposób formalny. Odmienność rzeczy zostałaby tym samym zastąpiona odmiennością sposobu istnienia, różnica realna różnicą formy realności. Krótko mówiąc, jeden i ten sam obiekt istniałby jednocześnie na dwa sposoby: w umyśle i poza nim (stanowisko takie określam mianem synchronicznego multiegzystencjalizmu $)^{21}$.

Co ciekawe, niektóre wypowiedzi samego Descartesa wskazują na jego aprobatę dla tego rozwiązania. Taką sugestię zawiera już przedłożona przez niego definicja obiektywnego sposobu istnienia: „przez obiektywną rzeczywistość idei rozumiem bytowość rzeczy przedstawionej przez ideę, o ile zawiera się ona w idei [...]. Cokolwiek bowiem ujmujemy jako [występujące] w przedmiotach idei, to istnieje w sposób obiektywny w samych ideach"22. Wrażenie to wzmacniają nadto inne fragmenty Medytacji: „Jeżelibyśmy [...] założyli, że w idei znajduje się coś, czego nie ma w jej przyczynie, to pochodziłoby to $\mathrm{z}$ niczego. A chociaż wielce niedoskonały jest ten rodzaj istnienia, dzięki któremu rzecz jest w naszym umyśle (intellectus) obiektywnie przez ideę, to zaiste nie jest on jednak niczym, a zatem nie może powstać z niczego. Nie powinienem też przypuszczać, że skoro rzeczywistość, którą

${ }^{19} \mathrm{~W}$ dalszej części artykułu rozwijam tezy nakreślone wstępnie w pracy Esse est percipi?, s. $50-51,60$.

${ }^{20}$ Mogłoby się wprawdzie wydawać, że nawet akcydentalna różnica w sposobie istnienia wystarcza do przedmiotowego odróżnienia dwóch obiektów. W istocie jednak u podstaw rozróżnienia konstytutywnych i niekonstytutywnych komponentów przedmiotu leży założenie, że tylko te pierwsze mają znaczenie dla jego tożsamości.

${ }^{21}$ B. Żukowski, Esse est percipi?, s. 50-51, 59-60.

${ }^{22}$ R. Descartes, Medytacje, s. 161. 
oglądam w moich ideach jest tylko obiektywna, to nie potrzeba, by ta sama rzeczywistość była formalnie w przyczynach owych idei, lecz że wystarczy, by była i w nich także w sposób obiektywny; albowiem tak, jak ów obiektywny sposób przynależy do idei z ich własnej natury, tak formalny sposób istnienia przynależy do przyczyn idei, przynajmniej do pierwszych i głównych, z ich natury" ${ }^{23}$. Wreszcie, odpowiadając na zarzuty Caterusa Descartes stwierdza otwarcie: „idea jest to sama rzecz pomyślana, o ile jest obiektywnie w intelekcie”24, przy czym „istnienie obiektywne w intelekcie” oznacza „że rzecz pomyślana $[. .$.$] istnieje \mathrm{w}$ intelekcie $\mathrm{w}$ taki sposób, $\mathrm{w}$ jaki zwykły istnieć jego przedmioty - do tego stopnia, że idea słońca to samo słońce istniejące w intelekcie, wprawdzie nie formalnie jak na niebie, lecz obiektywnie, czyli w taki sposób, w jaki zwykły przedmioty istnieć w intelekcie. Oczywiście ten sposób istnienia jest o wiele mniej doskonały od sposobu istnienia rzeczy poza intelektem, lecz [...] nie jest z tego powodu zupełnie niczym"25.

Przyjęcie omawianego rozwiązania prowadzi jednak do paradoksalnych konsekwencji. Skoro bowiem przedmiotowe rozróżnienie rzeczy i idei okazuje się fikcją, fikcją jest także zachodzący między nimi kauzalny związek przekazu własności - zamiast dwóch, powiązanych relacyjnie obiektów mamy do czynienia z jednym obiektem uobecniającym się na dwa sposoby. Konkluzja ta nie tylko podaje zaś $\mathrm{w}$ wątpliwość powszechne przeświadczenie o radykalnie dualistycznym charakterze Kartezjańskiej metafizyki, opartej rzekomo na ostrym odróżnieniu substancji rozciągłych od duchowych, lecz także falsyfikuje z pozoru jeszcze bardziej oczywistą tezę o reprezentacjonistycznym charakterze jego stanowiska epistemologicznego. Absolutnie podstawowym składnikiem wszelkiego reprezentacjonizmu jest bowiem ścisłe odróżnienie idei od rzeczy, reprezentacji od tego, co reprezentowane (bez którego nie sposób zanegować możliwość bezpośredniego poznania obiektów poza umysłem). Zniesienie różnicy przedmiotowej między ideą a jej pozaumysłowym korelatem, implikujące de facto możliwość niezmediatyzowanego poznania samych rzeczy materialnych, bezpośrednio wyklucza więc koncepcję Descartesa z grona teorii reprezentacjonistycznych. W konsekwencji, Kartezjański „reprezentacjonizm” okazuje się zakamuflowanym prezentacjonizmem ${ }^{26}$.

\footnotetext{
${ }^{23}$ Tamże, s. 46-47, wyróżnienie - B. Ż.

${ }^{24}$ Tamże, s. 107.

${ }^{25}$ Tamże, s. 108, wyróżnienie - B. Ż.

${ }^{26}$ B. Żukowski, Esse est percipi?, s. 60.
} 
Co ciekawe jednak, przyjęcie w punkcie wyjścia izomorfistycznej teorii reprezentacji uniemożliwia uniknięcie powyższej konkluzji, nawet w wypadku wyboru drugiego ze wspomnianych rozwiązań, a więc założenia konstytutywności sposobu istnienia idei i rzeczy materialnych ${ }^{27}$. Po pierwsze bowiem, przyjęcie, że sposób istnienia obu tych obiektów współdecyduje o ich tożsamości, podaje w wątpliwość, podkreślane przez Descartesa, twierdzenie o adekwatnym charakterze zachodzącej między nimi relacji reprezentacji ${ }^{28}$. Wraz z założeniem izmorfistycznej koncepcji reprezentowania jednym z warunków adekwatnej reprezentacji staje się bowiem zachowanie identyczności natury i metafizycznej struktury obiektu reprezentującego i reprezentowanego (sednem tej koncepcji jest wszak izomorfizm ontologicznej budowy idei i jej korelatu). Tymczasem, w wypadku współkonstytuowania natury idei i rzeczy materialnej przez sposób istnienia, różnica w sposobie bytowania obu tych obiektów w oczywisty sposób implikuje różnicę w ich naturze i przedmiotowej tożsamości. Co więcej, w takiej sytuacji nie może być mowy nie tylko o adekwatności poznania, ale w ogóle o relacji reprezentowania, a co za tym idzie o reprezentacjonizmie. Izomorfizm ontologicznej budowy idei i jej korelatu jest bowiem w wypadku omawianej koncepcji reprezentacji warunkiem nie tylko reprezentowania adekwatnego, ale reprezentowania w ogóle. Zachodząca między ideą a rzeczą materialną różnica w przedmiotowej tożsamości niweczy więc, niejako ex definitione, możliwość wszelkiego reprezentacyjnego ich skorelowania. Jako dwa różne, ontologicznie heterogeniczne obiekty, z samej swej natury są one niezdatne do powiązania relacją reprezentacji opartą na metafizyczno-strukturalnym „pokrewieństwie”29.

Powyższy wywód pokazuje, że obie metody rozstrzygnięcia problemu konstytutywności sposobu istnienia idei i rzeczy prowadzą w istocie nieuchronnie do paradoksalnych konsekwencji (toteż stanowisko samego Descartesa w tej kwestii jest w zasadzie nieistotne z czysto teoretycznego punktu widzenia). Niezależnie od obranego rozwiązania, już samo przyjęcie izomorfistycznej teorii reprezentacji zmusza bowiem, paradoksalnie, do zanegowania reprezentacjonistycznego charakteru konstruowanej przy jej pomocy koncepcji epistemologicznej. Ostateczny wniosek z przeprowadzonych w tym tekście analiz ma więc charakter ogólny: reprezentacjonizm oparty na izmorfistycz-

\footnotetext{
${ }^{27}$ Por. następujący fragment Medytacji (s. 47): „tak, jak ów obiektywny sposób przynależy do idei z ich własnej natury, tak formalny sposób istnienia przynależy do przyczyn idei, przynajmniej do pierwszych i głównych, $\mathrm{z}$ ich natury".

${ }^{28} \mathrm{Na}$ twierdzeniu tym opiera się m. in. jego dowód istnienia świata, zob. przyp. 15.

${ }^{29}$ B. Żukowski, Esse est percipi?, s. 60.
} 
nej teorii reprezentowania, przynajmniej w tej jej wersji, którą przedstawił Descartes, jest stanowiskiem wewnętrznie sprzecznym.

\author{
Abstract \\ Realitas formalis/realitas obiectiva. \\ The Paradox of Descartes' representationism
}

Keywords: Descartes, representationism, mind, idea, mode of existence

The paper discusses some aspects of the highly original theory of representation, developed by Descartes in his 'Meditations', and based on the ontological isomorphism of ideas and their material correlates. In the course of the analysis it is shown that the Cartesian theory involves unavoidable problems with discrimination or correlation of the objects in question, which is connected with the problem of constitutiveness of their modes of existence. Consequently, the conclusion of the paper is that representationism based on the isomorphistic theory of representation turns out to be self-contradictory. 